\title{
Participation and Development: Perspectives from the Comprehensive Development Paradigm
}

\author{
Joseph E. Stiglitz*
}

\begin{abstract}
This paper investigates the relationship between economic and social development. Contrary to the view of those who believe in the existence of a tradeoff between democracy and growth, the paper contends that consensus-building, open dialog and the promotion of an active civil society are key ingredients to longterm sustainable development. Development is a participatory process. "Best practices" or reforms that are imposed on a country through conditionality may very well fail to produce lasting change. They will tend to undermine people's incentives to develop their own capacities and weaken their confidence in using their own intelligence. Success in a knowledge-based economy requires a highly-educated citizenry, involved in the process of shaping and adapting ideas and policies. Participation and democracy in turn call for greater transparency and accountability in both the corporate and government sectors.
\end{abstract}

\section{Introduction}

The relationship between democracy and development has long been debated. In the years immediately following World War II, there was a belief (articulated, for instance, in Paul Samuelson's classic textbook) in a tradeoff between democracy and growth. The Soviet Union, it was argued, had grown faster than the countries of the West, but in order to do so had jettisoned basic democratic rights. Later, with the enormous success of the East Asian economies in the 1960s and 1970s, the lack of full participatory democracy in many of the most successful countries was once again seen as reflecting these tradeoffs.

A subject of this importance has not escaped the statisticians' close scrutiny, with the kind of ambiguity that we have come to expect from such cross-sectional and timeseries analyses-compounded by severe measurement problems. ${ }^{1}$ The host of factors that affect growth and that interact with each other make it difficult to identify with clarity the precise role of any particular factor. Even if we could establish a positive correlation, it would be necessary to ascertain a causality: does democracy promote growth or does growth promote democracy? If democracy is a "luxury" good, then those with higher incomes, or who see their incomes rising faster, will want more of this "luxury."

While the data may leave open the question of the precise relationship between the variables, the data - and the Soviet experiences—have made it clear that there is not the strong kind of tradeoff once envisioned. Countries can strive for openness and participation without fear that it will hamper development. Furthermore, research at both the macroeconomic and microeconomic levels has provided considerable insight into some of the ingredients that contribute to successful long-term growth. I will argue

\footnotetext{
* Stiglitz: Uris Hall Room 814, Mail Code 9142, Graduate School of Business, Columbia University, New York, NY 10027, USA. Tel: +1 (212) 854-0671; Fax: +1 (212) 854-8059; E-mail: jes322@columbia.edu.
} 
that broadly participatory processes (such as "voice," openness, and transparency) promote truly successful long-term development. This is not to suggest that those processes guarantee success, or that there are no risks inherent in these processes. Some societies that are highly participatory, at least in formal structure, have failed to achieve development success. But it does mean that an understanding of the centrality of open, transparent, and participatory processes in sustainable development helps us to design policies-strategies and processes - that are more likely to lead to longterm economic growth and that reinforce the strengths of the processes themselves.

I shall relate these lessons to the comprehensive development paradigm that is emerging, ${ }^{2}$ and more broadly, to the transformation of the world's economy from an industrial economy to a knowledge economy. ${ }^{3}$

\title{
2. Participation and the Transformation of Society
}

The comprehensive development paradigm sees development as a transformative movement. As I put it in my Prebisch Lecture (1998a) last fall:

\begin{abstract}
Development represents a transformation of society, a movement from traditional relations, traditional ways of thinking, traditional ways of dealing with health and education, traditional methods of production, to more "modern" ways. For instance, a characteristic of traditional societies is the acceptance of the world as it is; the modern perspective recognizes change, it recognizes that we, as individuals and societies, can take actions that, for instance, reduce infant mortality, increase lifespans, and increase productivity.
\end{abstract}

The comprehensive development paradigm contrasts with the dominant paradigm of the past half-century, which focused more narrowly on certain economic, or even more narrowly, allocative issues. It was argued that if only one could increase the supply of capital and the efficiency of resource allocations, development would occur. There is, in this sense, a close proximity in perspective between my predecessors as chief economist of the World Bank-Hollis Chenery, say, on the one hand, representing the modern evolution of the planning approach, and Anne Krueger, say, on the other hand, focusing on the reliance of market mechanisms. They disagreed on how best to improve the efficiency of resource allocations and to increase the level of investment, but they agreed that these were the central aspects of a growth strategy.

Since then we have come to see these perspectives as too narrow: they may be necessary conditions (and even that has been questioned), but they are far from sufficient. We now realize that "a dual economy is not a developed economy." That is, it may be possible to raise productivity and even change mindsets within an enclave of the economy without achieving a true development transformation of the society as a whole.

The inadequacy of the traditional, narrowly economic approach has been highlighted by the experience in Russia and many of the other economies in transition. According to the standard model, the former socialist regime, with its central planning (which by necessity was informationally inefficient), distorted prices, and attenuated incentives, led to outputs that were markedly below the economy's potential output. Reforms-privatization, free market prices, decentralization-even if not perfectly implemented, should have moved the economy far closer to its potential, and output 
should have risen. Since at the same time defense expenditures were cut back drastically, consumption should have increased markedly (unless savings increased-which did not happen). But in fact, output and consumption in most of the former socialist countries remains markedly below their levels of a decade ago, when the transition began. Part of the explanation lies in the destruction of organizational capital; part lies in the fact that far more than privatization is required to make an effective market economy; but yet another part of the explanation lies in the destruction of the already weak social capital, manifested in the growth of the so-called mafia.

If a change in mindset is at the center of development, then it is clear that attention needs to be shifted to how to affect such changes in mindset. ${ }^{5}$ Such changes cannot be "ordered" or forced from the outside, however well-intentioned the outsiders may be. ${ }^{6}$ Change has to come from within. The kinds of open and extensive discussions that are central to participatory processes are, I suspect, the most effective way of ensuring that the change in mindset occurs not only within a small elite, but reaches deep down in society. Indeed, there is a whole tradition that identifies "government by discussion" as key. ${ }^{7}$

\section{The Broad Range of Participation}

In this paper, I will use the term "participation" in the broadest sense, to encompass transparency, openness, and voice in both public and corporate settings. There are a variety of institutional arrangements that are consistent with "participation" in this sense. And the term "participatory processes" refers not just to those processes by which decisions are made in national governments, but also to processes used at local and provincial levels, at the workplace, and in capital markets.

This brings me to an important point: from this comprehensive development perspective, I would argue that participation does not refer simply to voting. ${ }^{8}$ Participatory processes must entail open dialog and broadly active civic engagement, and it requires that individuals have a voice in the decisions that affect them. ${ }^{9}$

Processes, not just outcomes, are key to this broader interpretation of participation. The stress on processes is a natural outgrowth not only of the increasing emphasis on equity, but also of our greater recognition of agency problems. That is to say, we now recognize the great importance of potential discrepancies between the actions taken by a party (the government, for example) and the interests of those that the party is supposed to serve. ${ }^{10}$ A government that engages in secrecy, making it impossible for citizens to have informed opinions about policies that are critical to their lives and the well-being of their country, weakens accountability and the quality of decisionmaking. ${ }^{11}$ A government that controls TV stations-often the way that a majority of the population becomes informed-or one that allows a small oligarchy to control the media also undermines accountability. Over the short term, a country may be able to engage in a meaningful national dialog on its future evolution without free elections; but in the long run, the dissonance may become too great. The legitimacy of those in decision-making positions will depend not only on their actions being in accord with these "democratic sentiments," but also on those positions being attained through open, electoral processes. While "buying elections" is almost everywhere a source of opprobrium-votes cannot or at least should not be traded in the marketplace as if they were a commodity ${ }^{12}$-it has been argued that the way electoral campaigns are run in many Western countries amounts to little more than "buying votes." Campaign 
contributions are required to "persuade" voters (via 30-second sound bites), and those providing the funds have undue influence in policy formulation. ${ }^{13}$

In many countries, an absence of rule of law and a lack of transparency both weaken the economy and undermine participatory processes. In some countries, for instance, while there are "rules" designed to ensure fair treatment of all, the rich and powerful have special access to the seats of political power and use that influence to obtain for themselves special favors and exemptions from the rules. They may also "buy" special access to the legislative and executive branches of government, thereby obtaining rules and regulations that are of benefit to them.

The adverse impacts of these policies on economic growth have been well documented. There is evidence, for example, that secure property rights and the rule of law-which tend to go hand in hand with a system of effective checks and balancesare associated with higher levels of investment and growth. ${ }^{14}$ In addition, recent research has shown that countries earn multiple benefits when they adopt good policies - which include open, transparent governance-and avoid the kinds of distorted policies that are associated with preferential treatment of special interests. Not only is growth faster, but foreign aid is also more effective in such contexts. ${ }^{15}$

Concentrations of economic power and wealth will almost inevitably be translated into attempts at political influence. The question is, what can be done about this? Part of any strategy is to limit these concentrations of wealth and economic power. This provides part of the justification for redistributive taxation, and especially inheritance taxation. It also provides part of the motivation for the antitrust laws enacted in the United States at the end of the last century. More broadly, Thomas Jefferson, the third president of the United States, the author of the American Declaration of Independence, and a great believer in democratic institutions, argued for the importance of smallholder agriculture if the newly founded American democracy was to flourish. Today, this view translates into active government support for small and medium-size enterprises. Part of the intent of the corporate restructuring currently going on in Korea is to limit the reach of this economic power; but there are concerns that in the process of rationalization of industry, concentrations of power in certain industries may actually increase. The temporary gains in efficiency may, I suggest, be more than offset by the inefficiencies introduced by excessive market power-and even if that were not the case, one should raise questions about the potential adverse effects on participation and openness.

There is a second prong to the strategy: strengthening the "checks" on abuses of this power and influence. This prescription encompasses at least three elements. The first is to strengthen civil society, as a source of countervailing power-from political parties, to unions, to consumer groups, to think tanks, and to a variety of other NGOs. In the parlance of modern economics, ensuring participatory processes, and promoting the public good more broadly, is itself a public good. As with other public goods, there will be too little provision of such participatory processes in the absence of public support. A strong civil society is an important element in a strategy of implementing meaningful democratic reforms.

Second, governments should not only increase transparency, but also recognize that there exists what I have termed the basic "right to know." Citizens have a right to know what the government is doing and why. They have a right to know if "exceptions" are made to certain rules and regulations. Again, to refer to the legal structure with which I am most familiar, the Freedom of Information Act has provided a way of enforcing 
at least a modicum of the citizens' right to know. Third, societies should extend citizens' rights to legal recourse, to sue. The United States recognized that political pressures might be brought to bear to induce governments not to act to break up monopolies and prevent anticompetitive practices, and as a result, the antitrust laws provided that any injured party could sue for triple damages. Though the law has been interpreted too narrowly and occasionally abused in the United States, such civil remedies seem particularly desirable in economies burdened by a history of large enterprises exercising excessive political influence. These are minimal steps in ensuring government accountability and the rule of law.

\section{Corporate Governance and Economic Efficiency}

Many of the issues I have just discussed are relevant not only to governments, but also to the governance of corporations. Corporations are public institutions: they collect funds from the "public" and invest them in productive assets. Workers too are stakeholders in corporations; given imperfections in labor mobility, a worker who is mistreated or fired cannot costlessly turn to other options (as he or she might in idealized neoclassical models). The managers of a corporation are in a fiduciary position of trust. Even if they are large shareholders, their actions affect others, from minority shareholders to bondholders to workers. While contractual arrangements between the corporations and each of these parties may delimit the scope of action of managers, the managers still have considerable room for action.

Laws affecting governance (and their implementation) have implications for both equity and efficiency. If minority shareholders or bondholders cannot be ensured fair treatment, they will not be willing to turn funds over to the corporation, and its growth will be limited, or else the firm will have to turn to banks as a source of finance. But even this recourse to bank finance has its limits: as leverage increases, the risk of bankruptcy increases. And if many firms in the economy have high leverage, then the economy as a whole may be threatened with a financial crisis, the costs of which may be borne by taxpayers and workers, not just the firm and its lenders. A strong legal system providing for corporate governance is essential to an effective capital market. And a strong bank regulatory system is essential if banks are not to provide the high levels of leverage that put the entire economy at risk.

Let me be clear: these are issues that involve both economics and participatory processes. For if businesses are allowed to delay the building of the necessary legal and regulatory framework or to subvert their effective implementation-because of insufficient participation by average citizens in decision-making - then those citizens will face adverse consequences that clearly are not of their own making.

While the legal system must, for instance, entail both strong protection of minority shareholders and the kinds of "fair trading" provisions incorporated in typical securities and exchange regulations, it must go beyond that, to ensure transparency and accountability. There need to be both civil and criminal actions, for instance, associated with fraud. Civil action, and the threat of it, can help make up for weaknesses or corruption in state supervision and enforcement: where civil action is possible, there are far more actors in the economy who have an incentive and a right to ensure enforcement of laws.

Today, the issues that I have discussed in this and the preceding section are recognized to be central to the success of an economy even under the narrower objec- 
tive of maximizing economic growth. As the 1997 World Development Report showed forcefully, if governments are not transparent, countries will fail to attract investment and growth will slow down. The recent World Bank report on Aid Effectiveness ${ }^{16}$ reinforced the conclusions about public governance as a contributor to growth. Recent events have suggested that corporate governance is also quite important; without a modicum of transparency and accountability in the corporate sector, investment and growth may lag. As Jim Wolfensohn has recently remarked, "free markets cannot work behind closed doors."

\section{Making Change Acceptable, and the Acceptance of Change}

As I emphasized in my Prebisch Lecture (1998a), development requires a change in mindset, and in particular, an acceptance of (and indeed a seeking out of productivity-enhancing) change. Change is often threatening-and sufficiently riskaverse individuals are willing to pass up opportunities for expected gain to avoid the downside risks. Participatory processes ensure that these concerns are not only heard, but also addressed; as a result, these processes dissipate much of the resistance to change. Consider an example that is particularly relevant in a time of globalization. As one who supports lowering trade barriers, I am nonetheless dismayed to note that all too often ardent free-trade advocates cavalierly dismiss the opponents, including those who stand to lose by free trade, and refer to them as "special interests" trying to protect their existing "rents." But among those hurt by trade reforms will be many who will lose their jobs; if the economy is suffering under an unemployment rate of $10 \%$ or more, there is a great risk of extended unemployment. And if the society lacks an adequate safety net, the unemployed worker risks true impoverishment, with disastrous effects on the lives of all family members. What is of concern to the worker is not just his loss of "rents," but the loss of his family's livelihood. Those experts who are not disciplined by having to be accountable to the citizenry too often ignore this. Inclusive processes make it more likely that these legitimate concerns will be addressed. In this way, they can ensure greater equality, and even allow more efficient outcomes-given that the loss in output from extended periods of unemployment may far outweigh the losses associated with the inefficient use of resources.

Participation is thus essential to effect the systemic change in mindset associated with the development transformation, and to engender policies that make changewhich is at the center of development-more acceptable. And because individuals have had a voice in shaping the changes, in making them more acceptable, change is likely to be accepted or even embraced, rather than reversed at the first opportunity.

\section{Participation and Project Effectiveness}

I have argued that participation is necessary for a fully effective, society-wide development transformation. Recent research has also begun to provide evidence for this point at the grassroots level, demonstrating the benefits of participation in development projects. ${ }^{17}$ It is not only that such participation brings to the project relevant information that outside development agencies (or even governments) are not likely to have. Participation also brings with it commitment, and commitment brings with it greater effort- the kind of effort that is required to make the project successful. ${ }^{18}$ For example, schools in which parents have a voice may be more successful partly because 
such participation engenders parental involvement in the school-and in their children's work. Water projects in which there has been more community participation are more likely to be successful, because participation will help support the kind of longterm maintenance that is required to keep them effective.

\section{The Knowledge Economy and Participation}

One of the major changes facing the developed and less developed world is the growth of the "knowledge economy." Elsewhere, I and others have argued that the knowledge economy will lead to a change in the ways of organizing production (and society more generally), changes which give rein to greater participation of individuals in decisionmaking. Indeed, success in the knowledge economy-whether at the firm level or at the level of the society-will require such change. Tayloristic vertical structures were designed to enforce and coordinate certain physical behaviors while knowledge-based work organization involves greater recognition of the autonomy and self-direction of the mind. Knowledge is best acquired not by passive rote memorization but by the active involvement of the learner. Learning is by doing, not by watching or memorizing. These activist principles were embodied, for example, in John Dewey's pragmatic philosophy of education. ${ }^{19}$

To foster the active involvement of the learner, the motivation should ideally be intrinsic to the activity, not a superadded carrot or stick. While external incentives can modify short-term behavior, they usually will only temporarily override rather than change the internal system of motivation. When the extrinsic incentives are removed, behavior reverts to the previous motives. All of these principles are fundamental for the knowledge-based transformation of a developing country. "Best practices" or reforms that are imposed on a country through conditionality ("carrots and sticks") may very well fail to produce lasting change. They will tend to undermine people's incentives to develop their own capacities and weaken their confidence in using their own intelligence. There is a real danger that an external development agency, instead of acting as a catalyst or midwife to empower change, will only short-circuit people's learning activities and reinforce their feelings of impotence. The external incentives may temporarily overpower the springs of action that are native to the institutional matrix of the country, but that will probably not induce any lasting institutional reforms.

Broad participation in the vital activities of a developing society, like shop-floor participation in a company, is at least helpful, and perhaps even necessary to foster a lasting transformation. Active involvement brings commitment to the lessons being learned and ownership of the results. Participation and involvement is not just a matter for government officials or managers; it needs to reach deeper to include those who are often excluded and who are key to the strengthening of social and organizational capital. ${ }^{20}$ Outside experts can encourage "ownership" of "best policies" through persuasion, but the degree of ownership is likely to be much greater if those who must carry out the policies are actively involved in the process of shaping and adapting, if not reinventing these policies in the country itself.

Success in a knowledge-based economy will also require a highly educated citizenry, with strong higher-level cognitive skills, and it will require an effective, and decentralized, communications network, like the Internet. Both of these enhance the possibilities of more effective participation, and make it more difficult to suppress it. 


\section{Participatory Processes and the Effectiveness of Decisions}

I began this paper by referring to the debates earlier in this century concerning the tradeoff between democracy and development. Underlying that debate was the hypothesis that participatory processes inhibited the kind of quick decision-making required for rapid economic growth. Supporters of this view sometimes make an analogy to the military, a highly hierarchical organization in which prices play little role. Few have suggested the use of market mechanisms for the allocation of scarce military resources in the middle of a war. Presumably, there is a belief that over short periods of time and for well-defined objectives, centralized control may be a more effective organizational form. ${ }^{21}$

Earlier in this century, rapid industrialization was viewed very much in the same terms: resources had to be marshaled quickly, which made the military model an attractive one to many societies. The Soviet Union, for example, saw time as of the essence. With the state and society threatened by hostile outside forces, its leaders felt that delay would be highly costly, and therefore development had to be imposed from above at rapid speed-and, as it turned out, at great cost.

There has been regrettably little work defining clearly the circumstances under which hierarchical decision-making is more effective than decentralized market mechanisms (see Stiglitz, 1975; Sah and Stiglitz, 1986). It appears that while markets may work far more efficiently in the long run, there may be short-run circumstances-often entailing dramatic changes in the direction of resource allocation, such as when a country goes to war-in which market mechanisms are either too slow or too unreliable. Certainly, the experience of extended periods of unemployment and underutilization of capacity - as illustrated by the Great Depression, and perhaps by the frequent financial crises which have plagued the world's economies over the past quarter century ${ }^{22}$ - suggests that market mechanisms do not always work quickly to allocate resources efficiently.

Open, participatory processes may result in delay. Take an example from my own country, the United States. It has been more than two decades since changes in demography and in the pace of productivity increase made it apparent that the US social insurance system was not financially viable. And yet, until recently, the political processes have not found it possible to begin to address the underlying problemseven in the case of solutions that appear to be supported by almost all experts, such as correcting the bias in the cost of living adjustment.

But as maddeningly slow as open political processes sometimes seem to be, it is not clear that less participation yields results any more quickly on average. Consider how different types of governments might react when faced with an insolvent banking system. An autocratic government may indeed move quickly and effectively to address the problem, if it chooses to pursue the best interests of society. But if instead it is beholden to financial-sector leaders and fears losing their support, the government may well use public funds to keep a sinking system afloat for as long as possible, before finally being forced into real reform. Compared with the latter case, a participatory political system-one that represents the interests of depositors and taxpayers as well as moneyed interests-might well mobilize more quickly to confront the problem. ${ }^{23}$

In any event, offsetting any potential costs of openness and participation are, I believe, their overwhelming advantages. Most of the literature has focused on the advantages of decentralizing decision-making, which-if done right—can give more 
people a chance to participate in those decisions. ${ }^{24}$ I do not want to review here all the arguments-the lower variability of decision quality that comes with decentralized decisions, ${ }^{25}$ the fact that rejected projects get a "second chance," which implies that fewer good projects (ideas) are rejected; ${ }^{26}$ or the opportunity for experimentation and learning that comes with decentralization.

\section{Participation and Political Sustainability}

But I do want to dwell for a moment on an argument for participatory processes that has perhaps received too little attention. Earlier, I argued that such processes make change more acceptable and more accepted. When democratic processes work well (that is, when the majority does not simply impose its wishes on the minority, or conversely), they entail a process of consensus-building. This means that once a new policy has been adopted, it can better weather the vicissitudes of the political process. ${ }^{27}$ For example, India's economic reforms of the past decade were not imposed from the outside, but were adopted from within, and in a way that has engendered broad support on the basic tenets. As a result, most of the key reforms have been sustained, even as governments have changed. More generally, when a society adopts reforms after a process of consensus-building, the political debate can move on to other issues-such as the next steps in reform-without feeling a continuous need to revisit prior decisions. By contrast, when there is a perception that the reforms were imposed from outside, the reforms themselves become the subject of political debate, lessening their sustainability.

\section{Economic and Social Development}

Too often, development is interpreted as being synonymous with economic development, the increase in per capita GDP. To be sure, one of the key factors differentiating more from less developed countries is per capita income. And increases in per capita income are clearly helpful for improving health and education, and for making it possible to pursue a host of other objectives that require resources. Figures 1 and 2 show that, by and large, countries with higher per capita incomes also have higher "social indicators." But while the two tend to move together, there is far from perfect correlation: certain countries and provinces (like Sri Lanka, Costa Rica, and Kerala) that have pursued active pro-poor social policies have managed to achieve social indicators that are far better than the norm for those at their per capita income. Korea has long shown similar trends, educating its children at far higher rates than we would have naively predicted based on income levels. Conversely, other countries that have failed to mind these social concerns have health and education levels far below what would be expected for a country at their level of income.

As I argued in my WIDER Lecture (1998c), we need to broaden our objectives, beyond an increase in per capita GDP, for instance, to sustainable and equitable development. Here, I want to emphasize another aspect, one that both has intrinsic value and is necessary for the attainment of many of these other objectives. I will call this aspect "social development," by which I mean the ability of a society to peacefully resolve conflicts and to address amicably sources of common concern when interests differ. Societies in which there is a high level of violence, either within the family or the community, would in these terms be marked by a low level of social development. 


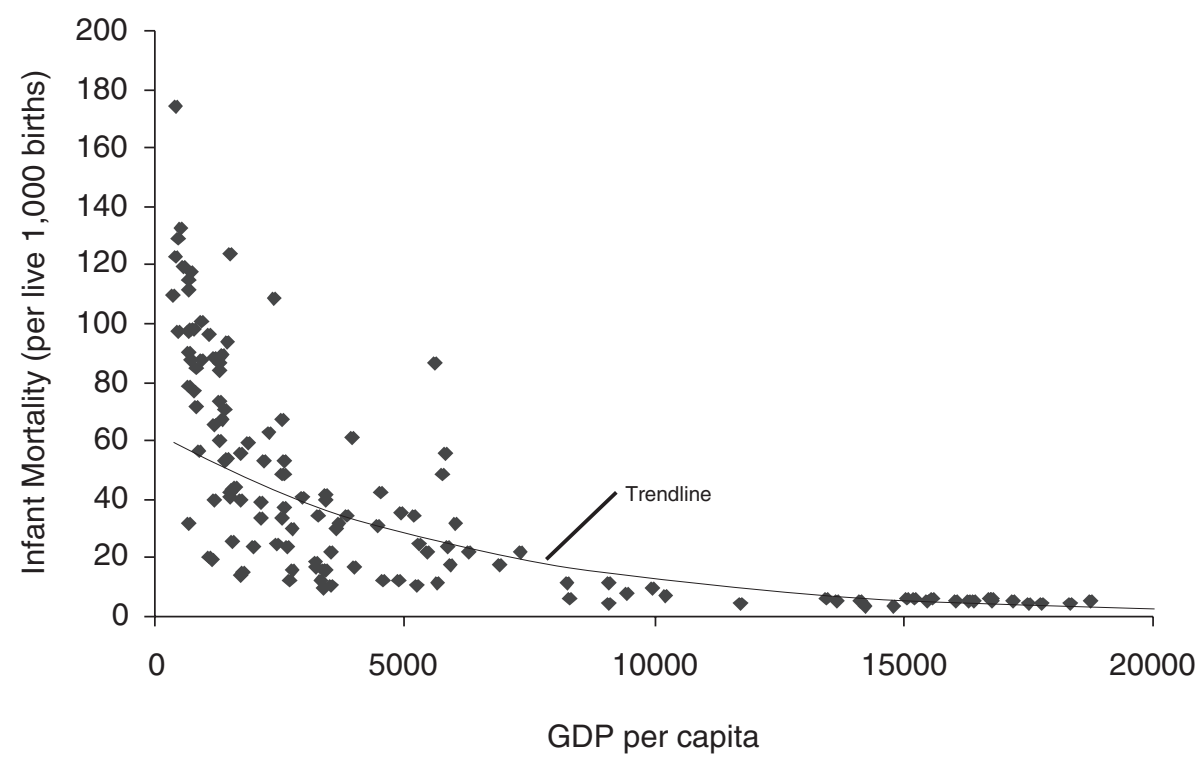

Figure 1. Infant Mortality and GDP per Capita, 1996

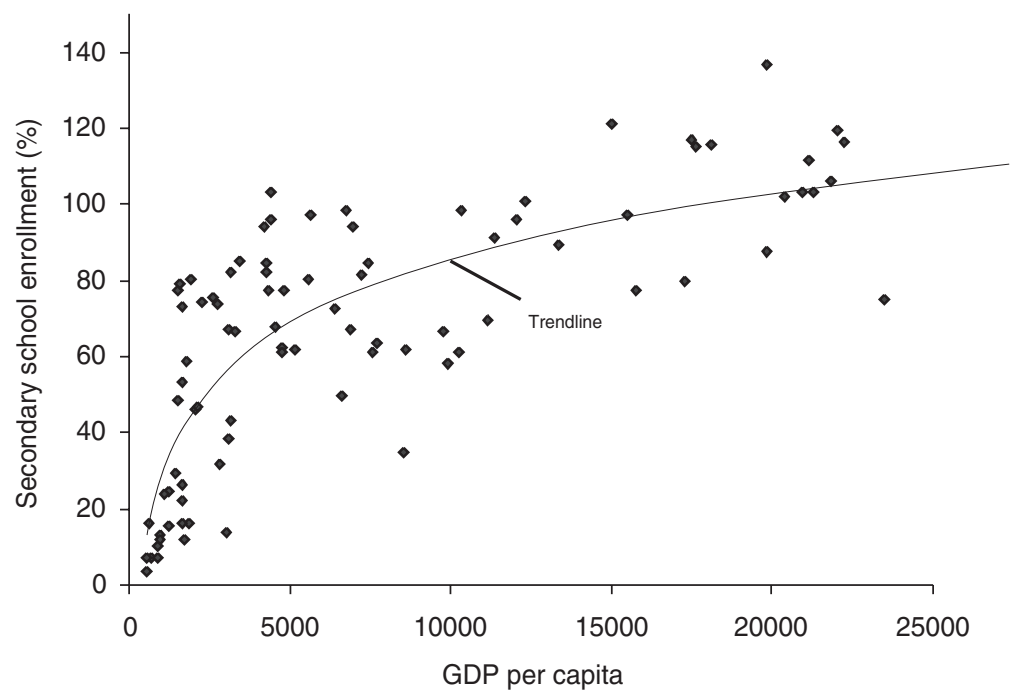

Figure 2. Secondary School Enrollment and GDP per Capita, 1995

Similarly, societies that suffer an extended "gridlock"-where important issues cannot be addressed over long periods of time because conflicting positions cannot be resolved, would also, in these terms, be marked by a low level of social development. More broadly, social development entails a greater sense of trust and responsibilitysuch as a credit culture, in which those who borrow "expect" to pay back the lendera higher level of social capital, and a greater "internalization" of some of the important externalities (such as those associated with the environment). ${ }^{28}$ 
Little need be said about the direct value of "social development" —in holding down crime, for example. The costs of violence in socially less developed societies go well beyond expenditures directed at protecting oneself against it; the threat of violence also gives rise to considerable anxiety and uncertainty, even if neither can adequately be assigned a price tag. But here, I want to focus not on this direct value, but on the relationship between social and economic development, as well as the impact of open, participatory, and transparent processes on that relationship.

\section{Social Development Promotes Economic Development}

Social development enhances economic development. Typically, "social" enforcement (reputation) mechanisms are more efficient than are "explicit" legal enforcement mechanisms. That is, it is more cost-effective if transactions take place in an environment in which business people have some confidence that they will not need to sue each time to have a contract enforced. Recent growth research has seemed to bear out this contention at the economy-wide level, showing that trust and shared civic norms are associated with better economic performance. ${ }^{29}$ Now that the development of financial institutions is widely recognized as an essential ingredient in a development strategy, a credit culture - that is, a socially developed culture that expects the repayment of debts, whether or not legal enforcement is imminent-is increasingly being recognized as contributing to financial depth. Similarly, both foreign and domestic business people will shy away from investing in an economy with a high level of crime, corruption, and violence, ${ }^{30}$ all symptoms of low levels of social development.

\section{But Economic Development Often Undermines Social Development}

The problem is that in the process of economic development, countries often regress in terms of social development. Social sanctions that previously worked well to internalize externalities within a community lose their potency when labor becomes highly mobile and when communities themselves become fragile. Social capital may deteriorate, before the country is able to establish the kinds of less personalized social capital associated with more advanced industrialized countries.

\section{Economic Policies that Fail to Pay Attention to the Social Dimension May Make Matters Worse}

Often, poor policy design has exacerbated this tendency for economic growth and change to fray the social fabric. I view with particular concern the increases in unemployment that are often associated with "adjustment." When workers are deprived of the opportunity to be meaningful participants in the community by working-when, through no fault of their own, they simply cannot find work-they lose self-esteem. Welfare is no substitute for work; and in any case, many developing countries lack even an adequate social safety net, so that the adverse consequences of unemployment are truly dire.

Other than impoverishment, unemployment can give rise to other social ills. As the Nobel Prize-winning economist Gary Becker has pointed out, crime stems at least in part from the expectation of economic gains. ${ }^{31}$ Those prospective gains loom larger, and the threat of punishment provokes less fear, when a person's other options for 
earning a living vanish. This is not to say that the typical unemployed worker turns to a life of crime, but only to note that despair and blocked opportunity can tear at the social fabric and reduce willingness to abide by laws. Since the resulting rise in crime levels is likely to exact significant economic and psychic costs, as I noted before, policymakers must take these costs into account when weighing the advantages of contractionary adjustment policies.

\section{Participatory Processes and the Restoration of Social Capital}

Open, transparent, and participatory processes can play an important role in preserving or, if necessary, re-establishing social capital. Participation itself can help create a sense of community, a sine qua non for a high level of social capital. If individuals believe that they have had meaningful participation in the decisions that are affecting them, they will be more willing to accept changes, even if they are adversely affected. But if they believe that those changes have been imposed on them, either by outsiders or by illegitimate governments who have not taken their concerns into account, then resentment is more likely to mount and to lead to socially destructive outcomes.

A minimal sense of community entails making sure those that are most disadvantaged-particularly those who face starvation or face severe medical problems-are taken care of, in at least a minimal way. The Nobel Prize-winning economist, Amartya Sen, has stressed that democratic societies simply do not allow famines to occur. ${ }^{32}$ Perhaps this is a low bar for a community to hurdle, but it is a crucial one nonetheless. Communities that do not allow such severe impoverishment are more likely to be trusted by a worker who faces potentially disruptive change because she will feel that her concerns are taken at least somewhat into account.

Open dialog with a free and vigorous press, with a diversified ownership of media (including TV) is, I would argue, essential for the development of this sense of community. With secrecy, and without such open dialog, there will always be the suspicion that decisions were made not on the basis of "community" interests, but on the basis of "special interests" (and often these suspicions are justified).

Let me elaborate briefly on this point. The problem is that with secrecy, individuals cannot tell from the outcomes alone whether their interests have received due attention. They observe outcomes that are clearly disadvantageous to them. They are told, for instance, that matters would have been even worse had not the given policies been pursued, or that in future things will be better. They may suspect that the interests of others-whether well-placed domestic business leaders or foreign lenders-may have been placed above the interests of less well-connected domestic actors, such as workers. In such circumstances, ensuring fair processes is essential; but if decisions are made in secret-or if there is not even full disclosure of the terms of an agreement- there will be little confidence that the processes were themselves fair.

\section{Economic Development can Promote Social Development}

While economic development in the past has often undermined social development, economic development today can serve to reinforce social development and participatory processes. For an essential ingredient of economic development is improved education and better communications. The latter enables individuals to be better informed about issues in a timely way, and the former puts individuals in a better 
position to use that information to form intelligent views concerning the merits of alternatives.

Well-designed education systems, which can both contribute to and be financed by economic development, have also played an important role in building social cohesion. Korea's education system is an excellent example. Although Korea has recognized the need to reform certain features of that system in the 1990s, over the past several decades the system has done much to reinforce social cohesion, in my view. The availability of mass education and the meritocratic principles underlying the system have strengthened confidence in the equity of social outcomes, in the process deflating any tendency toward social envy and dissent. On the flip side, poorly designed education systems that reinforce social stratification may well undermine a broad sense of social cohesion and impede social development.

\section{Social Cohesion, Economic Policy, and the Comprehensive Development Paradigm}

The central argument of this paper has been that open, transparent, and participatory processes are important ingredients in the development transformation-important both for sustainable economic development and for social development that should be viewed as an end in itself and as a means to more rapid economic growth.

Nowhere are such processes more important than in economic policymaking. While, to be sure, there are certain policies that make everybody worse off or everybody better off, in the real world many of the most important policy decisions entail choices among policies that cannot be so easily rejected or embraced. That is to say, there are real tradeoffs among policies: not only do some people gain more than others, but some actually lose.

Many have remarked at the increase in social tensions that followed upon the Latin American crisis of the 1980s. In many cases, education expenditures were cut back, and inequality and unemployment increased. We need not engage here in the debate whether adjustment policies exacerbated these problems, or whether they would have been worse, but for the adjustment assistance and the policies that accompanied that assistance. But what is clear is that, all too often, the process by which the decisions were made did not comport well with open, transparent, and participatory principles: not only were negotiations that led to adjustment typically conducted in secret, but even the outcomes sometimes were not fully disclosed.

My concern here is not only reality but also perception. Indeed, perceptions are sufficiently widespread to at least suggest that there may be some reality in them, and in any case, the perceptions themselves become part of the reality with which we have to deal. The widespread perception that I encounter is that adjustment packages of the 1980s often did not take into account as fully as they might have the social and economic consequences of the policies on the poor. In the East Asian crisis, these concerns have been compounded by another perception: that the adjustment packages went beyond actions that were necessary to deal with the crises. (Whether correct or not, this view has drawn enormous attention. Martin Feldstein, for instance, in his highly influential Foreign Affairs article, argued that the conditions on adjustment packages went not only beyond matters of direct concern to the crisis, but even into concerns that were more properly political than economic. In his view, these questions clearly should have been decided through participatory political processes. ${ }^{33}$ ) 
This perception - that economic decision-making on certain key questions has been less than fully participatory-has been reinforced by the secrecy in which negotiations often occur. Without prejudging whether secrecy is essential for market stability and for the successful conduct of negotiations (but see my Oxford Amnesty Lecture (1999b) for my reservations on these arguments for secrecy), the adverse consequences should be clear: as I have already noted, there will always be a suspicion that moneyed and vested interests, not common welfare, have dictated solutions. This problem is exacerbated when top decision-makers do not even go through the motions of weighing choices among various plausible alternatives. Instead, when decision-making is shielded from the public view, the recommended action is often adopted as if it were the only appropriate and feasible action-though it is perfectly transparent to most citizens that that is not the case. ${ }^{34}$

Whether we like it or not, whether it is justified or not, there is now in much of the world a legacy of suspicion and doubt. Opponents see in development conditionality an echo of the colonial bonds that their countries threw off only one or two generations ago. And while conditionality is at least widely perceived to have undermined transparency and participation, there is little evidence that it has achieved much in terms of better policies. ${ }^{35}$ The results should perhaps not be that surprising, given that policies imposed through conditionality are seldom politically sustainable. Indeed, in many cases, as we have noted, the policies are at least perceived to have contributed to the country's problems, undermined meaningful participation, and led to further breakdown of social cohesion. For example, privatization in Russia has not resulted in an effective market economy, and it increased inequality without any compensating increase in productivity or growth. Rather than providing incentives for wealth creation, it provided incentives for asset-stripping-with huge movements of "private" capital abroad. Moreover, the way that privatization was carried out resulted in media concentrations that undermined the viability of broad, informed public participation. Of course, none of these "failures" were themselves explicitly part of the recommendations, but conditionality may have done little to forestall them. While privatization was often a condition that was both explicit and highly visible, far less stress was placed on the institutional arrangements that might have mitigated these problems. Had a more broadly participatory process arrived at a homegrown privatization scheme which was then carried out on a schedule determined by domestic concerns, perhaps the combined wisdom and knowledge of the citizenry could have headed off the most egregious failures of privatization.

Those who provide funds-including both the IMF and the World Bank-must recognize that they have a fiduciary and moral responsibility to make sure that the funds are well spent. Future generations in the borrowing country will be obligated to pay back the loans, and unless the returns are sufficient, borrowing today will impoverish future generations, rather than enriching them. If funds end up financing capital flight at overvalued exchange rates, for example, it is hard to see how this enriches future generations! (Thus, it may be argued, it is not so much whether conditions are attached to making funds available that matters, but what those conditions are, and how they are arrived at.)

These are among the concerns that motivated the World Bank to seek new ways of working with developing countries. In the Comprehensive Development Framework that President Wolfensohn outlined in his annual speech in 1999, he proposed a new approach to development assistance. Not only did it emphasize the holistic nature of 
the development process, but it strove to create a new process, one that would entail a new set of relationships, not only between the Bank and the country, but within the country itself and between the country and all donor agencies. Central is the notion that the "country (not just the government) must be in the driver's seat."

One of the important results emerging from recent research on aid is not only that conditionality is ineffective, but that aid is highly effective in good policy environments. Moreover, one must recognize that funds are fungible: in effect, money goes to overall budgetary support. It makes sense therefore to give assistance to countries that have adopted good policies; a comprehensive development framework enhances the likelihood that the country will adopt such policies and sustain them. The emphasis on fungibility does not mean an end to project lending: budgetary assistance needs to be complemented with "knowledge" and "technical assistance," and project lending is often the most effective way to combine the two. But one must take into account the overall framework for that lending. In developing their strategies, countries may not approach matters exactly as international bureaucrats-unfettered by political constraints-would. I am not sure on whose judgment I would more often rely, particularly if my objective is the long-run political sustainability of reforms. Those within a country may be in a better position to make the difficult judgments on how best to create a sustainable consensus behind reforms. No decisions are more important than those that affect the economy. Clearly, the citizens need to be informed of the consequences of those choices-and on this there is often debate, even among so-called experts. No institution, whether domestic or international, has a monopoly on wisdom, and it is imperative that there be a full articulation of the evidence concerning the consequences of alternative policies.

\section{Concluding Remarks}

I have here discussed mainly general principles. But these principles translate into concrete actions. I illustrated this with one example in the previous section: how these principles necessitate a change in the way external assistance interacts with developing countries. I have also stressed the importance of the processes by which decisions are made-how consensus-building, open dialog, and the promotion of an active civil society are more likely to result in politically sustainable economic policies and to spur the development transformation. ${ }^{36}$

There are many other examples of how these principles can guide development action. In some cases, the perspectives put forth here reinforce arguments central to development policy in recent years: the importance of education, and, in particular, the education of women; the need for better communications, which can best be promoted by encouraging a competitive telecommunications sector; the central role of "good government" (inducing a lack of corruption); and the importance of the rule of law and of reducing scope for discretionary actions in a strategy to reduce corruption.

The view that I have offered here-with its emphasis on the simultaneous pursuit of social and economic development-places renewed emphasis on the need for governments to pursue policies that maintain full employment. There are many dimensions to this: avoiding crises-which necessitates strong governmental regulation of financial institutions and the pursuit of sound macroeconomic policies-and responding to crises in ways that minimize the length and depth of unemployment. 
It also places a renewed emphasis on the importance of competition policy. The origins of competition policy, it will be recalled, lie not only in the concern for promoting efficiency, but also the desire to avoid the concentrations of economic power that can corrode transparency and participatory processes. Nowhere are these concerns more important than in the media.

The comprehensive approach to development also raises new concerns: the structure of education systems, for instance, may lead to or perpetuate social stratification, undermining social cohesion, or it can be a key ingredient in nation building. More than just "efficiency in the delivery of services" is at stake. Given the importance of consensus formation, capacity building-creating the capacity for those within a country to forge their own development strategies and to have an active debate about the central tenets-needs to move more towards the center.

Though democracy has a long tradition-in the West, it dates back at least to the Greek city-states-it has been slow to evolve and remains highly fragile. It was only in the twentieth century that universal suffrage became the norm. Many countries have been slow to grant those basic rights that I believe to be so necessary for an effective participatory system - the right to a free press, free speech, the right to organize to pursue common objectives (both in general, and for workers in particular). Many governments continue not to recognize the people's fundamental "right to know," pursuing secrecy well beyond the domain where national security requires it.

Democracy, and participatory processes more generally, is also fragile. Repeatedly, we have seen high levels of social disorder lead to calls for "strong" (read "antidemocratic") government to restore the basic foundations of law and order without which individuals cannot live and work together. We have seen how economic policies, and the manner in which they are adopted, can contribute either to social cohesion or to social disorder. Countries that have experienced hyperinflation are well aware of the economic, and thus social, disruption to which the failure of the basic market mechanisms can give rise. But too often the wrong lesson has been read from these experiences: hyperinflation is seen as the underlying problem, and therefore it has to be avoided at all costs. But the real cause is the huge disruptions in the social and economic order that result from hyperinflation; therefore if policies designed to prevent inflation at the same time contribute directly to social and economic disorder, the consequences will be equally disastrous. (Indeed, Keynes, in his The Economic Consequences of the Peace (1920), predicted the adverse consequences of the terms of the Versailles Treaty, well before the particular way in which those consequences would manifest themselves became clear.)

The world has experienced financial and currency crises of increasing frequency and severity, ${ }^{37}$ with widespread economic and social repercussions. There is a growing consensus about the causes of the crises, and about the policies that must be adopted to reduce their frequency and severity and to mitigate the consequences (developing stronger safety nets, for example). ${ }^{38}$ But no safety net can fully replace the security provided by an economy running at full employment. No welfare system will ever restore the dignity that comes from work. It is imperative that countries not only implement policies that prevent crises and minimize their depth and adverse consequences, but also that they respond to these crises in ways that maintain as high a level of employment as possible.

But while globalization and economic change provide new challenges for sustainable comprehensive development, they also offer new opportunities and have made 
open, participatory, transparent processes essential for long-run success. This is as true for the private sector as for the public. As we start the twenty-first century, there is much to be learned from the failures of the last century. We cannot shut our eyes to the disasters brought on by totalitarian regimes: similar disasters must be avoided at all costs. Nor can we ignore the link between these failures and the economic and social disorder that preceded them.

We now know more about how to manage an economy than we did 75 years ago. We can hope that in the coming decades, we will make use of this knowledge, our broad understanding of the development process, and the new opportunities afforded by the changing economy to strengthen and extend development through comprehensive strategies. In this vision, these development strategies will incorporate social as well as economic development, arrived at through open, transparent, and participatory processes, that extend the fruits of development in a sustainable way to all the citizens of the developing world.

\section{References}

Bagehot, W., Physics and Politics, New York: Knopf (1948) [1869].

Barker, E., Reflections on Government, London: Oxford University Press (1967) [1942].

Becker, G. S., "Crime and Punishment: An Economic Approach," Journal of Political Economy 76 (1968):169-217.

Bruno, M., Crisis, Stabilization, and Economic Reform: Therapy by Consensus, Oxford: Oxford University Press (1993).

Bryce, J., The American Commonwealth, New York: G. P. Putnam's Sons (1959) [1888].

Coleman, J., "Social Capital and the Creation of Human Capital," American Journal of Sociology 94 (Suppl.) (1988):S95-120.

Caprio, G. and D. Klingebiel, "Bank Insolvencies: Cross-Country Experience," World Bank policy research working paper 1620 (1996).

Chibber, A., M. Dailami, J. de Melo and V. Thomas, Restructuring Economies in Distress: Policy Reform and the World Bank, World Bank and Oxford University Press (1995).

Clague, C., P. Keefer, S. Knack and M. Olson, "Property and Contract Rights in Autocracies and Democracies," Journal of Economic Growth 1 (1996):243-76.

Dasgupta, P., "Social Capital and Economic Performance," paper presented at World Bank Conference on Social Capital: Integrating the Economist's and the Sociologist's Perspective (1997).

Dewey, J., The Public and Its Problems, Chicago: Swallow Press (1927).

$\longrightarrow$, Freedom and Culture, New York: Capricorn (1939).

Department for Trade and Industry, Our Competitive Future: Building the Knowledge-Driven Economy, Cm 4176, London: HMSO (1998a).

Department for Trade and Industry, Our Competitive Future: Building the Knowledge-Driven Economy: Analytical Background. Available at www.dti.gov.uk/comp/competitive/an_ reprt.htm.

Feldstein, M., "Refocusing the IMF," Foreign Affairs 77 (March-April) (1998):20-33.

Fukuyama, F., Trust: The Social Virtues and the Creation of Prosperity, New York: Free Press (1995).

Hirschman, A. O., The Strategy of Economic Development, New Haven: Yale University Press (1958).

- Exit, Voice, and Loyalty: Responses to Decline in Firms, Organizations, and States, Cambridge, MA: Harvard University Press (1970).

Isham, J., D. Narayan, and L. Pritchett, "Does Participation Improve Performance? Establishing Causality with Subjective Data,” World Bank Economic Review 9 (1995):175-200. 
Isham, J., D. Kaufmann, and L. Pritchett, "Civil Liberties, Democracy, and the Performance of Government Projects," World Bank Economic Review 11 (1997):219-42.

Keynes, J. M., The Economic Consequences of the Peace, New York: Harcourt, Brace \& Howe (1920).

Knack, S. and P. Keefer, "Institutions and Economic Performance: Cross-Country Tests Using Alternative Institutional Measures," Economics and Politics 7 (1995):207-27.

- "Does Social Capital Have an Economic Payoff? A Cross-Country Investigation," Quarterly Journal of Economics 112 (1997):1251-88.

Knight, F., Freedom and Reform, New York: Harper \& Row (1947).

Lindblom, C., Inquiry and Change, New Haven: Yale University Press (1990).

Lindgren, C.-J., G. Garcia, and M. Saal, Banking Soundness and Macroeconomic Policy, Washington: International Monetary Fund (1996).

Luther, M., "Concerning Secular Authority," in F. W. Coker (ed.), Readings in Political Philosophy, New York: Macmillan (1942):306-29 [1523].

Mill, J. S., "On Liberty," in H. B. Acton (ed.), J. S. Mill: Utilitarianism, On Liberty and Considerations on Representative Government, London: J. M. Dent \& Sons (1972) [1859].

Morita, A., Made in Japan, New York: E. P. Dutton (1986).

Przeworski, A. and F. Limongi, "Political Regimes and Economic Growth," Journal of Economic Perspectives 7(3) (1993):51-69.

Ross, S., "The Economic Theory of Agency: The Principal's Problem," American Economic Review 63 (1973):134-9.

Sah, R. and J. E. Stiglitz, "The Architecture of Economic Systems: Hierarchies and Polyarchies," American Economic Review 76 (1986):716-27.

- "The Quality of Managers in Centralized Versus Decentralized Organizations," Quarterly Journal of Economics 106 (1991):289-95.

Sen, A. and J. Drèze, The Political Economy of Hunger, Oxford: Clarendon Press (1990).

Stiglitz, J. E., "Incentives, Risk and Information: Notes Towards a Theory of Hierarchy," Bell Journal of Economics 6 (1975):552-79.

- "Remarks on Social Capital: Integrating the Economist's and the Sociologist's Perspectives," World Bank Conference, 28 April (1997).

_ , "Towards a New Paradigm for Development: Strategies, Policies, and Processes," Paper given as Prebisch Lecture at UNCTAD, Geneva, 19 October (1998a).

_ , "Must Financial Crises Be This Frequent and This Painful?" Paper given as 1998

University of Pittsburgh McKay Lecture. Internet access: www.worldbank.org/html/extdr/ extme/js-092398/index.htm (1998b).

— Consensus," WIDER Annual Lectures 2 (1998c).

_ . "Public Policy for a Knowledge Economy," Remarks at the Department for Trade and Industry and Center for Economic Policy Research, London, UK 27 January (1999a).

— , "On Liberty, the Right to Know and Public Discourse: The Role of Transparency in Public Life," Paper presented as 1999 Oxford Amnesty Lecture (1999b).

"Symposia: Democracy and Development," Journal of Economic Perspectives 7(3) (1993).

Tobin, J., "On Limiting the Domain of Inequality," Journal of Law and Economics 13 (1970):26377.

Wolfensohn, J. D., "Annual Meetings Address: The Challenge of Inclusion," Washington: World Bank. Internet access: www.worldbank.org/html/extdr/am97/jdw_sp/jwsp97e.htm (1997).

, "Annual Meetings Address: The Other Crisis," Washington: World Bank. Internet access: www.worldbank.org/html/extdr/am98/jdw_sp/index.htm (1998).

_ , "A Proposal for a Comprehensive Development Framework (A Discussion Draft)," Washington: World Bank (1999).

World Bank, The World Bank Participation Sourcebook, Washington: World Bank (1996). 
"Crime and Violence as Development Issues in Latin America and the Caribbean," mimeo, Office of the Chief Economist, Latin America and the Caribbean. Washington: World Bank (1997).

-, “Assessing Aid: What Works, What Doesn't, and Why,” Washington: World Bank (1998).

\section{Notes}

1. For an earlier review, see "Symposia: Democracy and Development" (1993) in the Journal of Economic Perspectives, including the article by Przeworski and Limongi.

2. See Wolfensohn $(1998,1999)$ and Stiglitz (1998a).

3. See Department of Trade and Industry (1998a,b) and Stiglitz (1999a).

4. See Stiglitz (1998a).

5. "All [vicious development] circles result from the two-way dependence between development and some other factor, be it capital or entrepreneurship, education, public administration, etc. But the circle to which our analysis has led us may perhaps lay claim to a privileged place in the hierarchy of these circles inasmuch as it alone places the difficulties of development back where all difficulties of human action begin and belong: in the mind" (Hirschman, 1958, p. 11).

6. In the West, the clear recognition of the inability to externally force a change in mindset dates from the Reformation. "As little as another can go to hell or heaven for me, so little can he believe or disbelieve for me; and as little as he can open or shut heaven or hell for me, so little can he drive me to faith or unbelief" (Luther, 1942 [1523]). This insight was basic to the liberty of conscience and the attitudes of religious tolerance fostered in Europe after the Reformation. 7. See, for example, John Stuart Mill (1972 [1859]), Walter Bagehot (1948 [1869]), James Bryce (1959 [1888]), John Dewey (1927, 1939), Ernest Barker (1967 [1942]), Frank Knight (1947), and Charles Lindblom (1990).

8. "In theory, the democratic method is persuasion through public discussion carried on not only in legislative halls but in the press, private conversations and public assemblies. The substitution of ballots for bullets, of the right to vote for the lash, is an expression of the will to substitute the method of discussion for the method of coercion" (Dewey, 1939, p. 128).

9. See Hirschman (1970) for a discussion of "voice."

10. Agency theory is one of the principal strands in the modern theory of the economics of information. See, for example, Ross (1973), Stiglitz (1975), and the huge literature that followed. The essential point is that because of imperfections of information, actions of agents are not perfectly observable, and one cannot infer whether the agent took the "appropriate" action from observing outputs alone.

11. See Stiglitz (1999b).

12. Some free marketeers would disagree with this proposition. For an excellent discussion of the rationale for why voting should not be so treated, see Tobin (1970).

13. Lindblom makes this point in a particularly challenging way. "Among the defects of the existing competition of ideas, none seems more impairing and more easily remedied, given the will, than that well-financed communications, whether well-financed by the state, by private organizations, or by wealthy elites, overpower poorly financed ones. Many societies have accepted, at least as a principle, that children should deserve an education whether their parents can afford it or not, and that everyone deserves some forms of life-protecting medical services regardless of ability to pay. But no society has yet grasped the importance of separating rights of communication from ability to pay" (Lindblom, 1990, p. 296).

14. See Knack and Keefer (1995) and Clague et al. (1996).

15. See World Bank (1998).

16. See World Bank (1998).

17. See Isham et al. (1995) and Isham et al. (1997). 
18. "But, over time, development experience has shown that when external experts alone acquire, analyze, and process information and then present this information in reports, social change usually does not take place; whereas the kind of 'social learning' that stakeholders generate and internalize during the participatory planning and/or implementation of a development activity does enable social change" (World Bank, 1996, p. 5).

19. Dewey recognized as well the connection between political and economic conditions. "If you wish to establish and maintain political self-government, you must see to it that conditions in industry and finance are not such as to militate automatically against your political aim" (1939, p. 53).

20. See Wolfensohn (1997) for a discussion of the importance of inclusion in the development process.

21. The time-limited effectiveness of "military" methods was conveyed by Talleyrand's quip that one can "do anything with a bayonet except sit on it."

22. While such crises have marked capitalism from its origins, crises appear to be more frequent and deeper. See Caprio and Klingebiel (1996) and Lindgren et al. (1996).

23. I am indebted to Phil Keefer for this example.

24. By "decentralization," I refer here not just to governmental decentralization, but to any process (including market processes) that allow larger numbers of people to have inputs into decisions.

25. The extreme failures of the twentieth century-from Stalin to Hitler to Pol Pot-have all arisen in totalitarian regimes. This observation is consistent with the theoretical predictions of Sah and Stiglitz (1991).

26. See, for example, Sah and Stiglitz (1986).

27. In Japanese management practice, the slower but more effective process of participatory decision-making is likened to careful transplantation. "It is a time-honored Japanese gardening technique to prepare a tree for transplanting by slowly and carefully binding the roots over a period of time, bit by bit, to prepare the tree for the shock of the change it is about to experience. This process, called nemawashi, takes time and patience, but it rewards you, if it is done properly, with a healthy transplanted tree" (Morita, 1986, p. 158).

28. See, for example, Coleman (1988), Dasgupta (1997), Putnam (1993), Fukuyama (1995), and Stiglitz (1997).

29. See Knack and Keefer (1997).

30. See, for example, World Bank (1997).

31. See Becker (1968).

32. See Sen and Drèze (1990).

33. See Feldstein (1998).

34. Even if it were, a dialog behind closed doors would certainly not convince them otherwise. 35. See Chibber et al. (1995). Much of the conditionality concerns "timing"-certain actions (for example, the privatization of a particular company) are required to occur within a particular time horizon. Even if conditionality increased the speed of privatization slightly, the benefits of doing so may well not be worth the cost: the economic losses from a slight delay may be small compared to the gain from allowing the process of democratic decision-making to work its course. And indeed, in many cases, by encouraging excessive speed, the manner in which privatization has been conducted has been far from ideal. Governments have received far less than they would have in a more orderly process, and the magnitude of economic restructuring associated with privatization (and therefore the gains in efficiency) has been far smaller than it might have been. In several countries, the privatization process has resulted in undermining, rather than strengthening, confidence in market processes.

36. The late World Bank Chief Economist, Michael Bruno (1993), also argued that such processes have been effective means of addressing issues of macro stability.

37. See Caprio and Klingebiel (1996).

38. See, for example, Stiglitz (1998b). 
Copyright of Review of Development Economics is the property of Wiley-Blackwell and its content may not be copied or emailed to multiple sites or posted to a listserv without the copyright holder's express written permission. However, users may print, download, or email articles for individual use. 